Jurnal Ilmiah Ibnu Sina, 6(2), Oktober 2021,368-378

p-ISSN: 2502-647X; e-ISSN: 2503-1902

\title{
STUDI ETNOMEDISIN PADA MASYARAKAT 5 DESA KECAMATAN SECANG KABUPATEN MAGELANG
}

\author{
Rizka Amalia, Alfian Syarifuddin* \\ Departemen Farmasi, Fakultas Ilmu Kesehatan, Universitas Muhammadiyah \\ Magelang, Jawa Tengah \\ Email*: alfiansy@ummgl.ac.id
}

Artikel diterima: 5 Agustus 2021; Disetujui: 24 September 2021

DOI: https://doi.org/10.36387/jiis.v6i2.747

\begin{abstract}
ABSTRAK
Pemanfaatan tumbuhan sebagai bahan ramuan pengobatan tradisional merupakan tradisi masyarakat di Indonesia. Namun, pemanfaatan tanaman untuk pengobatan yang diwariskan turun temurun belum terdokumentasi dengan baik. Salah satu langkah solusi yang dilakukan adalah studi etnomedisin di masyarakat, dalam penelitian ini adalah 5 Desa yang berada di Kecamatan Secang, Kabupaten Magelang. Teknik pengambilan sampel yang digunakan adalah snowball sampling dengan observasi menggunakan instrument dan wawancara. Jumlah sampel responden sebanyak 388 responden. Hasil penelitian menunjukkan bahwa masyarakat memanfaatkan 96 spesies tumbuhan dari 47 famili. Terdapat 3 jenis penyakit yang menggunakan tanaman dalam pengobatannya dengan nilai ICF 1 , yaitu keseleo, mimisan, dan pelancar haid. Bagian tanaman yang paling banyak digunakan untuk pengobatan adalah daun dengan persentase $42.61 \%$. Cara pengolahan yang paling sering digunakan dengan teknik direbus dengan persentase $65.10 \%$ dengan cara pemakaian, yaitu diminum sebesar 77.05\%. Masyarakat paling sering mengkonsumsi tumbuhan obat dengan frekuensi $2 x$ sehari dengan persentase $74.87 \%$. Masyarakat biasanya menggunaan pengobatan selama sakit/ kuratif dengan persentase sebesar $76.74 \%$. Masyarakat mendapatkan tumbuhan dari pekarangan sendiri dengan persentase $54.24 \%$. Pengetahuan mengenai pengobatan berasal dari keluarga (turun-temurun) dengan persentase $72.43 \%$. Dari beberapa hasil analisis tersebut dapat digunakan sebagai acuan pada saat melakukan verifikasi ilmiah pengujian praklinik kepada hewan uji.
\end{abstract}

Kata Kunci: Etnomedisin, Kabupaten Magelang, Tanaman Obat.

\section{ABSTRACT}

The use of plants for traditional medicines are community tradition in Indonesia. However, the use of plants for hereditary treatment has not been well documented. One of the solutions is an ethnomedicine study, in this study 5 villages located in Secang District, Magelang Regency. The sampling technique used is snowball sampling with observation using instruments and interviews. The number of respondents sample is 388 respondents. The results showed that the community utilized 96 plant species from 47 families. There are 3 types of diseases that use 
plants in their treatment with an ICF value of 1, namely sprains, nosebleeds, and menstrual flow. The most widely used parts for treatment are leaves (42.61\%). The most frequently used processing method is the boiling technique with a percentage of $65.10 \%$ by way of use, which is drinking $77.05 \%$. People most often consume with a frequency of $2 x$ a day (74.87\%). People usually use treatment during illness/ curative (76.74\%). People get plants from their own yard (54.24\%). Knowledge about treatment comes from family (hereditary) (72.43\%). From some of the results, it can be used as a reference when conducting scientific verification of preclinical testing on test animals.

Keywords: Etnomedicine, Kabupaten Magelang, Medicinal plants

\section{PENDAHULUAN}

Pemanfaatan tumbuhan, hewan dan mineral dalam menunjang kehidupan disetiap masyarakat memiliki kearifan local dan kebijaksanaan. Berdasarkan penelitian yang dilakukan oleh Handayani et al. 2011; Verma et al. 2014 dalam jurnal (Erzegovina et al., 2019) di Indonesia pemanfaatan tumbuhan sebagai pengobatan tradisional lebih popular dibandingkan dengan hewan, sebesar $11,1 \%$ telah memanfaatkan tumbuhan dan sebesar $8,7 \%$ telah memanfaatkan hewan.

Pemanfaatan tumbuhan, erat hubungannya dengan tradisi masyarakat di Indonesia. Salah satunya di Kecamatan Secang, Kabupaten Magelang pada Desa Jambewangi, Desa Madusari, Desa Ngadirojo, Desa Girikulon, dan Desa Karangkajen yang memiliki kekayaan alam yang melimpah. Hal ini karena letaknya berada dipedesaan dan dekat dengan pegunungan. Sehingga berpotensi memiliki banyak tumbuhan di daerah tersebut. Serta masyarakatnya masih menggunakan tanaman obat sebagai pengobatan.

Berdasarkan latar belakang tersebut, peneliti tertarik untuk meneliti studi etnomedisin. Berdasarkan penelitian ini, diharapkan dapat mengungkap pengetahuan masyarakat dalam memanfaatkan tumbuhan sebagai pengobatan tradisional.

\section{METODE PENELITIAN}

Penelitian ini merupakan penelitian sains observasional di bidang Pengembangan Obat Tradisional yang dilakukan di 5 Desa, Kecamatan Secang, Kabupaten Magelang. 
Jurnal Ilmiah Ibnu Sina, 6(2), Oktober 2021,368-378

p-ISSN: 2502-647X; e-ISSN: 2503-1902

Teknik pengambilan sampel

Dimana, $\mathrm{N}_{\text {ur: }}$ Jumlah informan menggunakan snowball sampling dengan instrument/ kuesioner dan wawancara. Dokumentasi berupa yang mengetahui dan atau video. Berdasarkan hasil perhitungan rumus Slovin dari 5 desa didapatkan 387 sampel dengan taraf kepercayaan menggunakan tumbuhan untuk mengobati penyakit. Sedangkan $\mathrm{N}_{\mathrm{t}}$ : Jumlah tumbuhan yang digunakan untuk mengobati penyakit (Komoreng et al., 2019) $95 \%$.

Analisis ICF (Informant HASIL DAN PEMBAHASAN

Consensus Factor) merupakan nilai yang menunjukkan keseragamaan Masyarakat yang menjadi informasi antar informan yang responden dalam penelitian ini menjadi sampel dalam penelitian berjumlah 388. Data demografi (Sakinah, 2018). ICF dihitung sebagai berikut:

$\left(\mathrm{N}_{\mathrm{ur}}-\mathrm{N}_{\mathrm{t}}\right) /\left(\mathrm{N}_{\mathrm{ur}}-1\right)$.

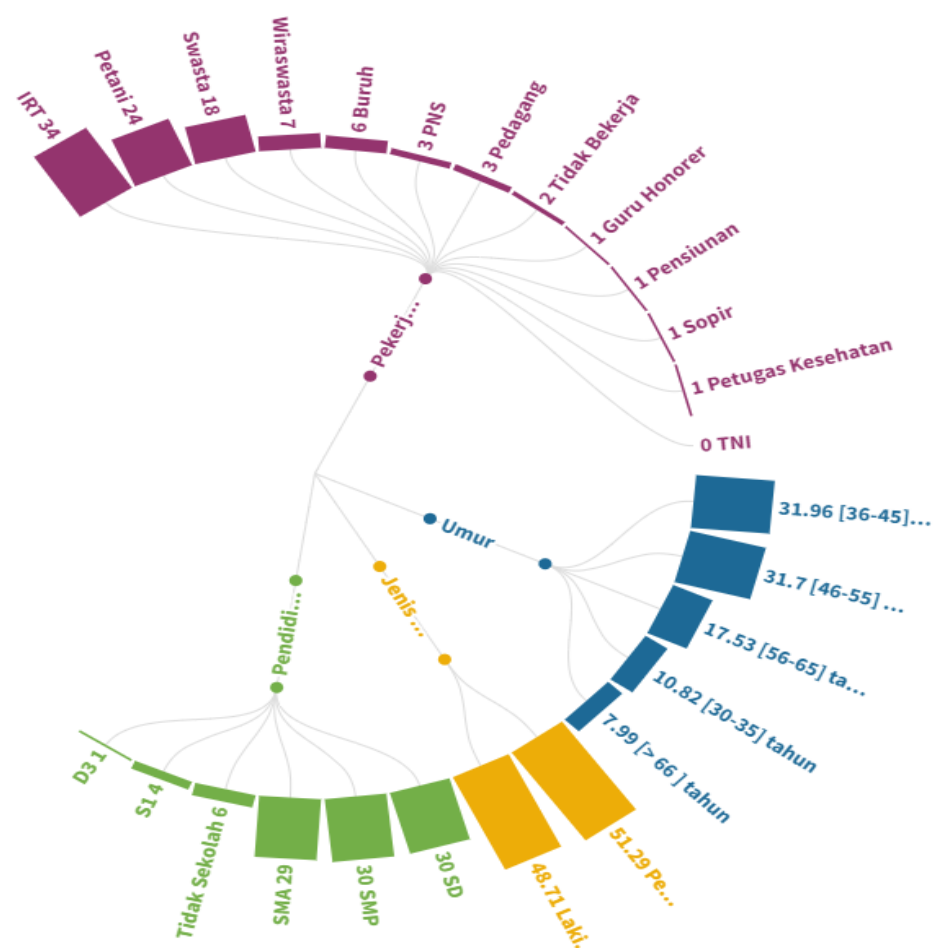

Gambar 1. Data Karakteristik Responden dalam Bentuk Persentase 
Jurnal Ilmiah Ibnu Sina, 6(2), Oktober 2021,368-378

p-ISSN: 2502-647X; e-ISSN: 2503-1902

Berdasarkan karakterisitik responden yang dapat dilihat pada Gambar 1. paling banyak berusia 3645 tahun dengan jumlah 124(31.96\%), Berdasarkan penelitian yang dilakukan oleh (Silalahi et al., 2018) menyatakan bahwa usia berpengaruh terhadap pengetahuan pemanfaatan tumbuhan.

Tingkat pendidikan yang paling tinggi yaitu SD dengan persentasi sebesar 118(30\%). Berdasarkan penelitian yang dilakukan oleh (Ikaditya, 2016) menyatakan bahwa tingkat pendidikan berpengaruh terhadap faktor kemampuan untuk menerima informasi. Semakin tinggi tingkat pendidikan semakin luas cara pandang dan cara berpikirnya terhadap lingkungan sekitar. Persentase pekerjaan paling tinggi bermata pencaharian IRT dengan persentase 132 (34\%). Berdasarkan penelitian yang dilakukan oleh (Jennifer \& Saptutyningsih, 2015) tingkat pendapatan individu tidak ada hubungannya dengan penggunaan obat tradisional.

Persepsi masyarakat terkait tumbuhan obat mayoritas mengetahui dan menggunakan tumbuhan sebagai obat seperti yang disajikan pada Tabel 1.

Tabel 1. Persepsi Masyarakat Terhadap Tumbuhan Obat

\begin{tabular}{lcc}
\hline Persepsi Masyarakat & & $\mathbf{n}(\mathbf{\%})$ \\
\hline \multirow{2}{*}{ Pengetahuan tentang tumbuhan obat } & Ya & $388(100 \%)$ \\
& Tidak & $0(0.0 \%)$ \\
\hline \multirow{2}{*}{ Keberadaan tumbuhan obat disekitar tempat tinggal } & Ya & $379(97.68 \%)$ \\
& Tidak & $9(2.32 \%)$ \\
\hline Informasi yang pernah didapat tentang tumbuhan & Ya & $388(100 \%)$ \\
obat & Tidak & $0(0.0 \%)$ \\
\hline & Selalu & $0(0.0 \%)$ \\
Frekuensi Penggunaan & Sering & $217(55.93)$ \\
& Kadang-kadang & $167(43.04)$ \\
& Tidak Pernah & $4(1.03 \%)$ \\
\hline
\end{tabular}

Masyakat

mempunyai

pengetahuan tumbuhan sebagai pengobatan, dan bertempat tinggal dekat dengan keberadaan tumbuhan obat. Berdasarkan penelitian yang dilakukan oleh (Jennifer \&
Saptutyningsih, 2015) menyatakan bahwa tempat tinggal berpengaruh terhadap pemilihan penggunaan obat tradisional. Masyarakat yang tinggal di daerah desa lebih banyak menggunakan pengobatan tradisional 
Jurnal Ilmiah Ibnu Sina, 6(2), Oktober 2021,368-378

p-ISSN: 2502-647X; e-ISSN: 2503-1902

dibandingkan yang tinggal di daerah

Tabel 2. Nilai ICF

perkotaan. Masyarakat telah menunjukkan keseragamaan informasi

mendapatkan informasi bahwa antar informan yang menjadi sampel

tumbuhan obat dapat digunakan dalam penelitian dalam hal ini

sebagai pengobatan dan sering keseragaman terkait pemanfaatan

menggunakan tumbuhan sebagai tumbuhan terhadap penyakit tertentu.

pengobatan.

Analisis

kuantitatif

menggunakan nilai ICF yang disajikan

pada

Tabel 2. Hasil ICF (Informant Consensus Factor)

\begin{tabular}{clc}
\hline No & \multicolumn{1}{c}{ Khasiat } & ICF \\
\hline 1 & Keseleo, Mimisan, Pelancar Haid & 1.00 \\
\hline 2 & Nafsu makan, Diare, Penghangat Badan, Batuk & $0.91-0.99$ \\
\hline 3 & $\begin{array}{l}\text { Luka, Demam, Panas Dalam, Asam Urat, Hipertensi, Anemia, Pelancar } \\
\text { Asi, Pegal Linu, Maag }\end{array}$ & $0.81-0.90$ \\
\hline $\mathbf{4}$ & $\begin{array}{l}\text { Penyubur rambut, Antihiperglikemik, Perut kembung, Anti kanker, } \\
\text { Antikolesterol, Pelancar BAB, Antiseptik }\end{array}$ & $0.71-0.80$ \\
\hline $\mathbf{5}$ & Gatal-gatal, nyeri gigi & $0.61-0.70$ \\
\hline $\mathbf{6}$ & $\begin{array}{l}\text { ISK, Masuk angin, DBD, Bau badan, Vitamin C, Keputihan, Dehidrasi, } \\
\text { Antibiotik }\end{array}$ & $0.51-0.60$ \\
\hline $\mathbf{7}$ & $\begin{array}{l}\text { Penguat gigi, Imunitas, Menjernihkan mata, Batu ginjal, TBC, Sakit } \\
\text { mata, Diet }\end{array}$ & $0.31-0.40$ \\
\hline $\mathbf{8}$ & Penghangat bayi, Panu, Liver & $0.21-0.30$ \\
\hline $\mathbf{9}$ & $\begin{array}{l}\text { Kista, Stroke, Sakit jantung Paru-paru, Membersihkan Rahim, } \\
\text { meningkatkan trombosit, Kadas, Hepatitis, Bau mulut }\end{array}$ & $0.11-0.20$ \\
\hline $\mathbf{1 0}$ & \begin{tabular}{l} 
Sakit perut, Sariawan, Radang tenggorokan, Malaria, Asma, Ambeien \\
\hline
\end{tabular} & $0.01-0.10$ \\
\hline
\end{tabular}

Berdasarkan hasil ICF dapat digunakan untuk mengobati 1 (Informant Consesus Factor) yang disajikan pada

Tabel 2 dari 58 jenis penyakit. Terdapat 3 jenis khasiat dengan nilai 1 , yaitu keseleo, mimisan, dan pelancar haid. Nilai ICF (Informant Consesus Factor) dengan nilai 1 dikatakan bahwa banyak responden menyebutkan dari beberapa tumbuhan jenis penyakit.

Rimpang kencur digunakan untuk menyembuhkan keseleo. Berdasarkan penelitian yang dilakukan oleh (Soleh \& Megantara, 2016) Manfaat dari kencur yaitu untuk meredakan kaki keseleo. Kandungan yang dimiliki yaitu saponin, flavonoid, polifenol, dan minyak atsiri. Khasiat 
Jurnal Ilmiah Ibnu Sina, 6(2), Oktober 2021,368-378

p-ISSN: 2502-647X; e-ISSN: 2503-1902

sebagai penyembuh mimisan kunyit (curcuma longa linn) dapat menggunakan tumbuhan daun sirih digunakan untuk melancarkan hijau (Piper betle L). Berdasarkan menstruasi, menghilangkan sumbatan penelitian yang dilakukan oleh dalam peredaran darah, meluruhkan (Bestari et al., 2020) menyatakan darah menstruasi, antiinflamasi, bahwa daun sirih hijau (Piper betle L) kalagoga, karminativa, antibakteri, digunakan sebagai mimisan. dan astringensia.

Kandungan dalam tumbuhan ini yaitu

Bagian tumbuhan yang alkaloid, tannin, saponin, alkaloid, dan digunakan dan cara pengolahan bagian minyak atsiri. Khasiat sebagai tumbuhan yang dimanfaatkan untuk pelancar haid menggunakan rimpang pengobatan disajikan pada Gambar 2. kunyit (curcuma longa linn). Informasi tersebut digunakan untuk Berdasarkan penelitian yang pengembangan tumbuhan tersebut dilakukan oleh (Anugrahhayyu et al., pada saat akan dilakukan verifikasi 2018) menyatakan bahwa rimpang ilmiah.
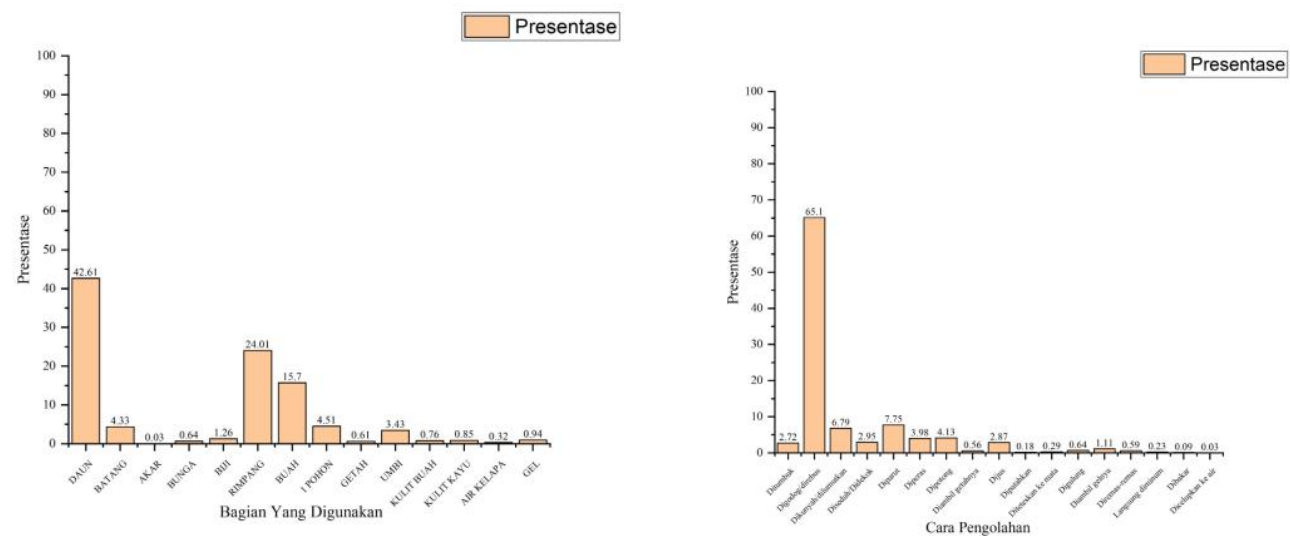

Gambar 2. Persentase Bagian yang Digunakan dan cara pengolahan sebagai Pengobatan

Daun merupakan bagian mengandung klorofil, yang terdapat tumbuhan yang persentasenya paling zat senyawa antioksidan, zat tinggi. Berdasarkan penelitian yang antiperadangan, dan zat yang dapat dilakukan oleh (Maulidiah, 2019) menyembuhkan penyakit. Penelitian bahwa daun dipercaya masyarakat yang dilakukan oleh (Dianto et al., memiliki kadungan obat karena 2015)menyatakan Daun mengandung 
Jurnal Ilmiah Ibnu Sina, 6(2), Oktober 2021,368-378

p-ISSN: 2502-647X; e-ISSN: 2503-1902

unsur zat-zat organic yang dapat saponin, dan alkaloid (Aslamiah \& digunakan sebagai penyembuh Haryadi, 2014). Pada penelitian yang penyakit. Hal ini karena daun dilakukan oleh (Puspita, 2019) merupakan tempat akumulasi hasil mengatakan bahwa proses perebusan fotosintesis.

Cara pengolahan dengan direbus merupakan persentase tertinggi. Penelitian yang dilakukan oleh (Ani et al., 2018) menyatakan bahwa, tujuan perebusan untuk menarik zat-zat aktif yang terkandung dalam tumbuhan menggunakan media air karena merupakan zat pelarut yang bersifat polar. Zat-zat bioaktif yang biasanya terdapat dalam tumbuhan yaitu golongan senyawa metabolit sekunder seperti golongan, flavonoid, tannin, agar tidak telalu lama karena dapat mengakibatkan rusaknya senyawa aktif yang terkandung di dalam tumbuhan tersebut. Masyarakat percaya cara direbus berkhasiat lebih efektif dibandingkan dengan cara lain. Hal ini telah dibuktikan oleh masyarakat yang telah mempraktekannya (Puspita, 2019).

Cara penggunaan tumbuhan obat dan frekuensi penggunaan tumbuhan obat disajikan pada Gambar 3 dan Gambar 4.

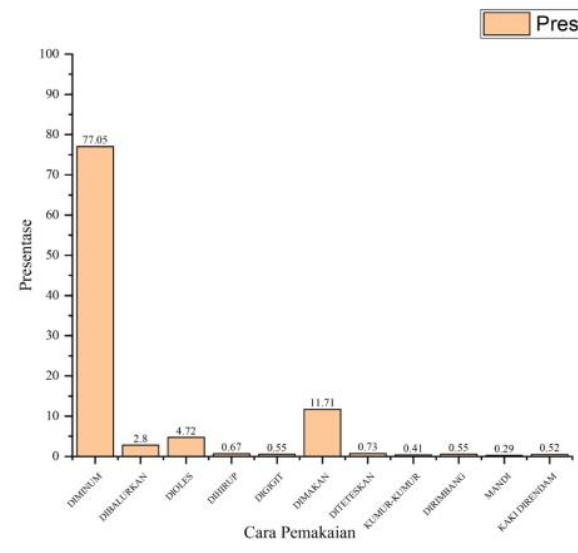

Gambar 3. Persentase Cara Penggunaan Tumbuhan Obat

Persentase paling tinggi cara pemakaian dengan cara diminum. Hal ini sejalan dengan penelitian yang dilakukan oleh (Efremila et al., 2015) bahwa masyarakat lebih banyak menggunakan tumbuhan sebagai pengobatan dengan cara diminum. karena masyarakat percaya bahwa cara ini memiliki reaksi yang cepat dan penyakit yang dirasakan akan sembuh 
Jurnal Ilmiah Ibnu Sina, 6(2), Oktober 2021,368-378

p-ISSN: 2502-647X; e-ISSN: 2503-1902

dibandingkan dengan cara

penggunaan yang lain.

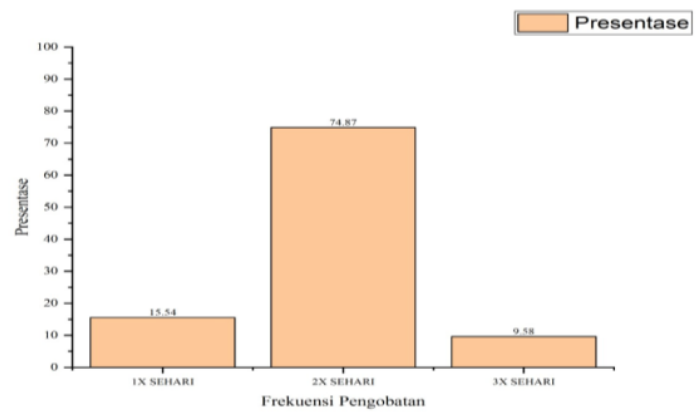

Gambar 4. Persentase Frekuensi Pengobatan

Frekuensi pengobatan paling sehari, penyakit dengan kategori tinggi, yaitu $2 \mathrm{x}$ sehari. Pengobatan sedang cukup dengan $2 \mathrm{x}$ sehari, dan dengan tumbuhan berkhasiat secara penyakit dengan kategori berat dapat efektif didalam tubuh ditentukan digunakan 3x sehari.

dengan frekuensi pemakaian.

Masyarakat menggunakan Frekuensi ini ditentukan dengan berat tumbuhan sebagai pengobatan dengan atau tidaknya suatu penyakit yang berbagai macam lama dalam diderita. Penyakit dengan kategori pengobatannya seperti pada Gambar ringan cukup dengan frekuensi $1 x \quad 5$.

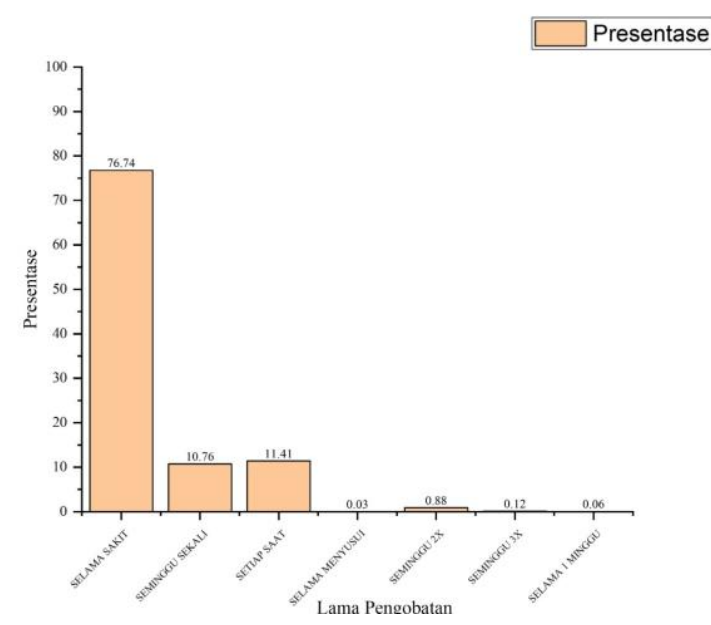

Gambar 5. Lama Pengobatan Tumbuhan Obat sebagai Pengobatan

Masyarakat di desa tersebut merupakan usaha yang dilakukan menggunakan tumbuhan sebagai untuk mengobati ketika sakit saja pengobatan selama sakit saja atau (Susanti, 2017). Tumbuhan obat dengan upaya kuratif. Upaya kuratif utamanya dapat digunakan untuk 
Jurnal Ilmiah Ibnu Sina, 6(2), Oktober 2021,368-378

p-ISSN: 2502-647X; e-ISSN: 2503-1902

terapi pencegahan atau preventif yang digunakan masyarakat dan terhadap suatu penyakit informasi pemanfaatan tumbuhan tertentu(Pertiwi et al., 2020). untuk pengobatan dapat dilihat pada

Berdasarkan asal tumbuhan Gambar 6.
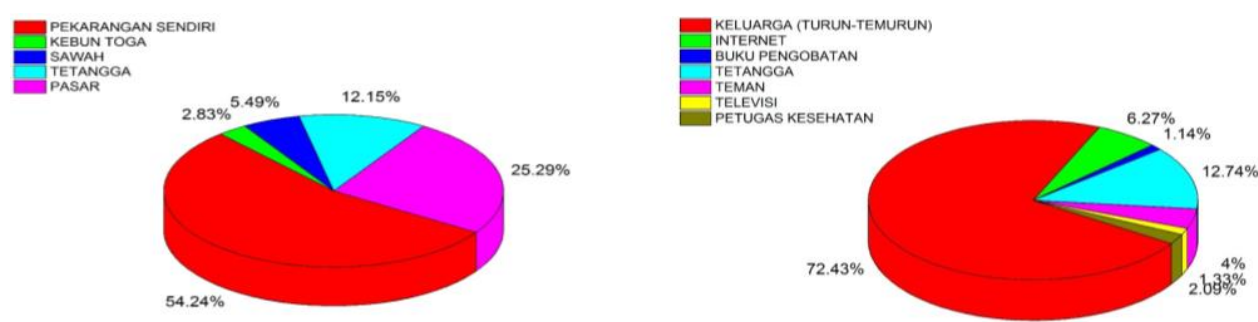

Gambar 6. Persentase Asal Tumbuhan dan informasi tumbuhan sebagai Pengobatan

Tumbuhan yang digunakan sebagai pengobatan berasal dari pekarangan sendiri dengan persentase tertinggi sebesar 54,24\%. Masyarakat terdorong untuk menanam tumbuhan obat di pekarangan rumah sebagai

Berdasarkan hasil penelitian, mayoritas masyarakat mengetahui informasi dalam penggunaan obat tradisional berasal dari keluarga (turun-temurun). Pada penelitian yang dilakukan oleh (Ismiyana, 2013) menyatakan bahwa keluarga merupakan memiliki peran yang penting dalam memberikan informasi mengenai pengobatan tradisional.

\section{KESIMPULAN}

Terdapat 3 khasiat yang mendapatkan nilai ICF (Informant upaya pengobatan pertama dan pencegahan bagi keluarga terhadap suatu penyakit (Sofian et al., 2013). Kebiasaan ini telah lama dilakukan terutama oleh para ibu rumah tangga (Sari et al., 2015).

Consesus Factor) tinggi yaitu khasiat sebagai keseleo, mimisan dan pelancar haid.

\section{UCAPAN TERIMA KASIH}

Peneliti ucapkan terimakasih kepada Dinas Kesehatan Kabupaten Magelang, masyarakat di 5 Desa, Kecamatan Secang, Kabupaten Magelang tepatnya di Desa Girikulon, Desa Jambewangi, Desa Karangkajen, Desa Madusari, dan Desa Ngadirojo, serta semua pihak yang telah terlibat dalam penelitian ini sehingga berjalan 
Jurnal Ilmiah Ibnu Sina, 6(2), Oktober 2021,368-378

p-ISSN: 2502-647X; e-ISSN: 2503-1902

dengan baik.

Efremila, Wardenaar, E., \& Sisillia, L. (2015). Studi Etnobotani Tumbuhan Obat oleh Etnis Suku Dayak di Desa Kayu Tanam Kecamatan Mandor Kabupaten Landak. Jurnal Hutan Lestari, 3(2), 234-246.

Ani, N., Rohyani, S. I., Sukenty, K., \& Aryanty, E. (2018). Potensi Pemanfaatan Tumbuhan Obat oleh Masyarakat di Taman Wisata Alam Madapangga (Studi Kasus: Desa Ngano, Kecamatan Madapangga, Kabupaten Bima, Nusa Tenggara Barat).

Anugrahhayyu, C. A., Darsini, N., \& Sa'adi, A. (2018). Jurnal Farmasi Dan Ilmu Kefarmasian Indonesia Vol. 5 No. 1 Juli 2018 1. Jurnal Farmasi Dan Ilmu Kefarmasian Indonesia, 5(1), $1-5$.

Aslamiah, S., \& Haryadi. (2014). Identifikasi Kandungan Kimia Golongan Senyawa Daun Pohon Kapuk (Ceiba pentandra L.) sebagai Obat Tradisional. Anterior Jurnal, 14(1), 11-19.

Bestari, R. S., Priawan, F. B., Rosyidah, D. U., \& Cahyo, F. D. (2020). Uji Efektivitas Ekstrak Daun Sirih ( Piper Betle L .) terhadap Mortalitas Larva Anopheles Aconitus. Jurnal Ilmiah Kesehatan, 15(4), 259-266.

Dianto, I., Anam, S., \& Khumaidi, A. (2015). Studi Etnofarmasi Tumbuhan Berkhasiat Obat Pada Suku Kaili Ledo di Kabupaten Sigi, Provinsi Sulawesi Tengah. Galenika Journal of Pharmacy, 1(2), 85-91.

Erzegovina, H., Kusrini, Mi. D., \&

Masy'ud, B. (2019).

Karakteristik dan Persepsi Masyarakat Terhadap Obat Tradisional Berbahan Herpetofauna di Jakarta dan Bandung (Community Characteristics and Perception of Traditional Medicine Made from Herpetofauna in Jakarta and Bandung ). 24(3), 293-302.

Ikaditya, L. (2016). Hubungan Karakteristik Umur dan Tingkat Pendidikan Terhadap Pengetahuan Tentang Tanaman Obat Keluarga (TOGA). Kesehatan Bakti Tunas Husada, 16(1), 171176.

Ismiyana, F. (2013). Gambaran Penggunaan Obat Tradisional Untuk Pengobatan Sendiri pada Masyarakat di Desa Jimus Polanharjo Klaten Naskah Publikasi.

Jennifer, H., \& Saptutyningsih, E. (2015). Preferensi Induvidu Terhadap Pengobatan Tradisional di Indonesia. Ekonomi Dan Studi Pembangunan, 16(1), 26-41.

Komoreng, L. V. B., Mayekiso, B., Mhinana, Z., \& Adeniran, A. L. (2019). An Ethnobotanical and Ethnomedicinal Survey of Traditionally Used Medicinal Plants in Seymour, South 
Jurnal Ilmiah Ibnu Sina, 6(2), Oktober 2021,368-378

p-ISSN: 2502-647X; e-ISSN: 2503-1902

Africa: An Attempt toward Digitization and Preservation of Ethnic Knowledge. Pharmacognosy Magazine, 14(60), 115-123. https://doi.org/10.4103/pm.pm

Maulidiah. (2019). Pemanfaatan Organ Tumbuhan sebagai Obat yang Diolah secara Tradisional di Kecamatan Kebun Tebu Kabupaten Lambung Barat.

Pertiwi, R., Notriawan, D., \& Wibowo, R. H. (2020). Pemanfaatan Tanaman Obat Keluarga (TOGA) Meningkatkan Imunitas Tubuh sebagai Pencegahan COVID19. Dharma Raflesia: Jurnal Ilmiah Pengembangan dan Penerapan IPTEKS, I8(2), 110-118. https://doi.org/10.33369/dr.v1 $8 \mathrm{i} 2.12665$

Puspita, I. R. (2019). Kajian Etnomedisin pada Masyarakat di Desa Benteng Gajah Kecamatan Tompo Bulu Kabupaten Maros.

Sakinah, P. (2018). Studi Etnofarmasi Penggunaan Tumbuhan Obat Untuk Mengobati Demam Pada Balita Oleh Masyarakat Suku Tengger Kecamatan Tosari Kabupaten Pasuruan. In Skripsi.

Sari, D. I., Yuniar, Y., Siahaan, S., Riswanti, \& Syaripuddin, M. (2015). Tradisi Masyarakat dalam Penanaman dan Pemanfaatan Tumbuhan Obat
Lekat di Pekarangan. Jurnal Kefarmasian Indonesia, 5(2), 123-132.

Silalahi, M., Nisyawati, \& Anggraeni, R. (2018). Studi Etnobotani Tumbuhan Pangan yang Tidak Dibudidayakan oleh Masyarakat Lokal Sub-Etnis Batak Toba, di Desa Peadungdung Sumatera Utara, Indonesia. Pengelolaan Sumberdaya Alam Dan Lingkungan, 8(2), 241-250. https://doi.org/10.29244/jpsl.8 .2.241-250

Sofian, Supriyatna, \& M, M. (2013). Peningkatan Sikap Positif Masyarakat dalam Pemanfaatan Tanaman Obat Pekarangan Rumah di Desa Sukamaju dan Girijaya Kabupaten Garut. Jurnal Aplikasi Ipteks Untuk Masyarakat, 2(2), 107-117.

Soleh, \& Megantara, S. (2016). KARAKTERISTIK MORFOLOGI BUNGA KENCUR (Kaempferia galanga L.). Karakteristik Morfologi Tanaman Kencur (Kaemferia Galanga L) Dan Aktivitas Farmakologi, 19(2), 109-116.

https://doi.org/10.21082/bullitt ro.v19n2.2008.\%p

Susanti, A. A. (2017). Upaya Pengobatan Promotif, Preventif, Kuratif, dan Rehabilitatif Demam Berdarah di Kecamatan Bulukerto, Wonogiri. 